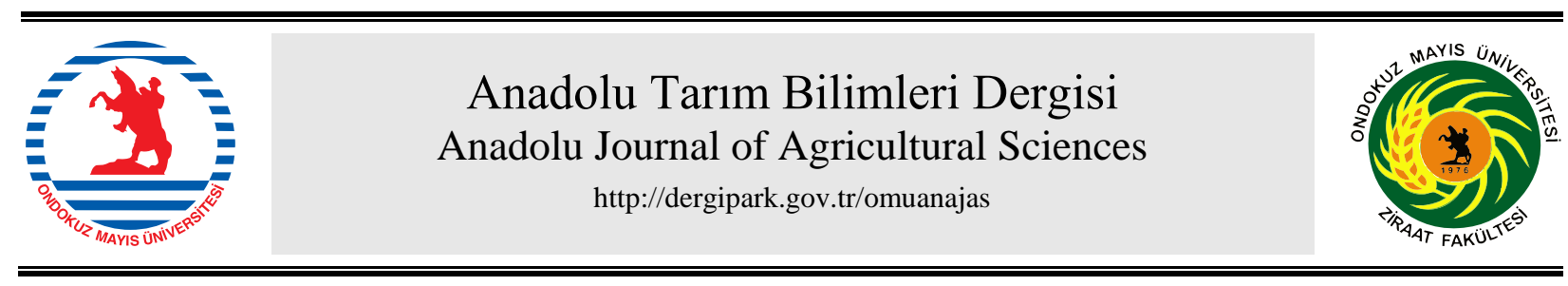

Araştırma/Research

Anadolu Tarım Bilim. Derg./Anadolu J Agr Sci, 33 (2018)

ISSN: 1308-8750 (Print) 1308-8769 (Online)

doi: 10.7161/omuanajas.394783

\title{
Nergis (Narcissus cv. 'Ice Follies') çiçeğinde yapraktan ethephon uygulamasının bitki boyu üzerine etkileri
}

\author{
Sevim Demir*, Fisun Gürsel Çelikel \\ Ondokuz Mayls Üniversitesi, Ziraat Fakültesi, Bahçe Bitkileri Bölümü, Samsun/Türkiye \\ *Sorumlu yazar/corresponding author: sevim.demir@omu.edu.tr
}

Geliş/Received 14/02/2018～Kabul/Accepted 29/09/2018

\begin{abstract}
ÖZET
Bu çalışmada kültür çeşidi (Narcissus cv. 'Ice Follies') nergis çiçeğinin saksıda yetiştiriciliğinde yaprak sprey yöntemi ile verilen etehphonun bitki boyu üzerine olan etkileri incelenmiştir. Serada saksılı olarak yetiştiriciliği yapılan Narcissus cv. 'Ice Follies' çiçeklerine bitki boyunun yaklaşık 7-10 cm olduğu dönemde 0, 1000 ve 2000 ppm dozlarında ethephon uygulamaları yapraktan sprey şeklinde yapılmıştır. Yapılan bu kimyasal uygulamaların çiçeklenme zamanı, çiçek sayısı, yaprak boyu, bitki boyu, çiçek ömrü ve yaprakların klorofil içeriği üzerine olan etkileri incelenmiştir. Ayrıca yapılan uygulamaların üretim sonrası (ev-ofis) koşullardaki etkisini inceleyebilmek amacıyla, serada yetiştirilen nergisler satış aşamasına geldikleri dönemde sıcaklığı $20{ }^{\circ} \mathrm{C}$ 'de olan laboratuvar ortamına alınıp burada ölçümlere devam edilmiştir. Yaprak sprey şeklinde yapılan uygulamalar neticesinde bitki boyu açısından en iyi sonucu $2000 \mathrm{ppm}$ ethephon uygulaması vermiş, bitki boyu $4.17 \mathrm{~cm}$ ile kontrole göre \% 69 oranında daha kısa olmuştur. 'Ice Follies' nergislerinde 1000 ppm ethephon uygulamasının da bitki boyu açısından oldukça etkili olduğu belirlenmiş, $4.45 \mathrm{~cm}$ ile kontrole göre $\% 67$ oranında daha kısa bitki boyu elde edilmiştir. Ethephon uygulamalarının yapıldığı bitkilerden daha kısa yaprak boyu elde edildiği, çiçek ömrü açısından ise uygulamalar arasında bir fark olmadığı tespit edilmiştir. Ayrıca yapraklarda birim alandaki klorofil miktarının ethephon uygulamalarının yapıldığı bitkilerde daha fazla olduğu belirlenmiş, en yüksek klorofil içeriği 82.6 CCI ile 1000 ppm ethephon uygulamasının yapıldiğ bitkilerde tespit edilmiştir. Yapılan uygulamaların üretim sonrası (ev-ofis) koşullardaki etkisi devam etmiş ve en kısa bitki boyunun $4.75 \mathrm{~cm}$ ile 2000 ppm ethephon uygulamasından elde edildiği belirlenmiştir.
\end{abstract}

\section{The effects of ethephon foliar spray on plant height of Narcissus cv. 'Ice Follies'}

\section{ABSTRACT}

In this study, effect of ethephon as foliar spray on plant height of narcissus (Narcissus cv. 'Ice Follies') grown in pots were investigated. When plants were 7-10 cm tall, 0, 1000, 2000 ppm ethephon were applied foliar spray. Effect of ethephon on the time of flowering, leaf length, plant height, flower life, chlorophyll content of leaves were determined. In addition, after narcissus were grown in pots in the greenhouse arrived at the sales stage to determinate the changes that occur in the plant height, plants were taken to the laboratory which was temperature held constant at $20{ }^{\circ} \mathrm{C}$. The shortest plant height was obtained from the $2000 \mathrm{ppm}$ ethephon treatment as given soil drench. In this treatment, plant heihgt was $4.17 \mathrm{~cm}$ and were $69 \%$ shorter than untreated control. The lower dose of ethephon (1000 ppm) was also effective on height control with $4.45 \mathrm{~cm}$ plant height and $67 \%$ shorter than untreated control. Ethephon application also shortened leaf lenght and there was no difference among application for flower life. Ethephon treatments were resulted higher chlorophyll content per unit area in the leaves than untreated controls. The highest chlorophyll contetnt was obtained from the plants were treated 2000 ppm ethephon with 82.6 CCI. The effects of treatments on plant height has been preserved in conditions laboratuary (home-office), the shortest plant height was obtained from 2000 ppm ethephon treatment with $4.75 \mathrm{~cm}$.

Keywords: Ethephon Foliar spray Narcissus Plant height 


\section{Giriş}

Soğanlı süs bitkilerinden olan nergislerin uzun boylu ve dağınık yapıda olması, saksıda kullanımını güçleştirmektedir. Saksılı bitkilerin kısa ve kompakt olması paketleme ve taşıma sırasında kolaylık sağladığı gibi bitkilerin pazarlanması sirasında da zarar görmelerini önler, ayrıca görünümleri yönünden de aranan bir özelliktir. Yetiştirilen çeşit kısa boylu bodur yapıda olsa bile, satış sonrası tüketici koşullarında 1 şık azlığından boyu uzamakta ve istenmeyen dağının bir yap1 kazanmaktadır (Çelikel ve ark., 2016). Boy kontrolü; çevresel faktörleri (1şık, sıcaklık vs.) kontrol altına alarak, ya da büyümeyi düzenleyiciler adı altında giberellin inhibitörleri kullanarak mümkün olmaktadır (Currey ve Lopez, 2014, Miller, 2012; Demir ve Çelikel, 2013; Çelikel ve ark., 2016). Bitkideki büyümeyi geciktirici etki, büyümeyi teşvik edici bir hormon olan giberellin sentezini azaltarak veya engelleyerek mümkün olmaktadır. Giberellin inhibitörlerinin yanında ethephon da bitkide boy uzamasını engellemek amaciyla kullanılmaktadir (Miller ve Olberg, 2016). Ethephon (2-chloroethyl phosphonic acid) bitkilerde etilen salınımını serbest bırakan bir bitki büyüme düzenleyicisidir. (Miller ve ark., 2012; Miller ve Olberg, 2016).

Yapılan çalışmalarda birçok nergis çeşidine 10002000 ppm dozlarında sprey şeklinde ethephon uygulanmasının bitki boyunu kontrol altına aldığ belirtilmiştir (Miller, 2002). Flurprimidol ve paclobutrazol 'Tete a Tete' nergis çeşidinin serada yetiştirilmesi süresince bitki boy uzunluğunu kontrol altına almamış fakat üretim sonrası değerlendirmede, bitki boyu ethephonun sprey şeklinde verilmesi, paclobutrazol ve flurprimidolün ise topraktan uygulanması ile kontrol altına alınmıştır (Krug ve ark., 2006). Ethephonun toprak 1slatma şeklinde farklı nergis çeşitlerine uygulanması ile bitki boyu kontrol altına alınmış fakat çiçeklenmeyi 2-3 gün kadar geciktirmiştir. Ethephonun uygulama dozu artıkça etkisi de artmıştır (Miller ve ark., 2012).

Narcissus cv. 'Ice Follies' çeşidi üzerine ethephonun etkisi ile ilgili dünyada sınırlı sayıda çalışma bulunmaktadır. Ülkemizde ise bu çeşitle ilgili dikim zamanının çiçek kalitesi üzerine etkisi ile ilgi çalışmalar yapılmış (Kebeli ve Çelikel, 2013) ancak boy kontrolü ile ilgili bir çalışmaya rastlanmamıştır. İşte bu çalışmanın amacı farklı dozlarda yapraktan uygulanan ethephonun kültür çeşidi nergis çiçeklerinin saksıda yetiştiriciliğinde bitki boyu ve diğer özellikler üzerine olan etkilerinin saptanmasıdır.

\section{Materyal ve Yöntem}

Bitkisel materyal: Bu çalışmada Narcissus poeticus $\mathrm{x}$ Narcissus pseudonarcissus türlerinin melezlenmesiyle elde edilen (Burnie ve ark., 1999), çevre genişliği ortalama $10 \mathrm{~cm}$ olan Narcissus cv. 'Ice Follies' soğanları kullanılmıştır. 'Ice Follies' soğanları 1 Ekim
2013 tarihinde Konya ilinde bulunan Asya Lale firmasından temin edilmiştir.

Kimyasal Materyal: Ethephon; Ethrel, Florel ve Efhun ticari adlarıyla bilinen ethephon bitkiler tarafindan hızla absorbe edilir ve doğal bitki hormonu olan etileni serbest bırakır, üretimini artırır. Ethephon uygulamasıyla meydana gelen etilen salınımı, bitkilerde apikal dominansiyi azaltır ve yan sürgünlerin gelişimini teşvik eder (Haver ve ark., 2003). Bu çalışmada Agrobest Grup Tarım İlaçları Tohum İmalat İthalat İhracat Sanayi ve Ticaret Anonim Şirketi'nden temin edilen Efhun ticari ismiyle bilinen \%48'lik ethephon yaprak sprey şeklinde 0,1000 ve 2000 ppm dozlarında bitkilere uygulanmıştır. Deneme 10 tekerrürlü olarak kurulmuştur.

Deneme Serasl: Deneme, Ondokuz Mayıs Üniversitesi Ziraat Fakültesi Bahçe Bitkileri Bölümü Süs Bitkileri Yetiştirme Serasında yürütülmüştür. Denemenin yürütüldüğü Süs Bitkileri Yetiştirme Seras1, $8 \mathrm{~m}$ genişliğe, $20 \mathrm{~m}$ uzunluğa ve $5.5 \mathrm{~m}$ yüksekliğe sahip polietilen plastik örtülü özelliklerine sahip bir seradır.

Laboratuvar: Serada saksıda yetiştirilen nergisler, satış aşamasına geldikten sonra laboratuvara taşınmıştır. Bitki boyunda üretim sonrası ev-ofis koşullarında meydana gelen değişimler ile bitki (çiçek) ömürleri daha önce bildirilen standart koşullarda (Çelikel ve Karaçalı, 1991; Çelikel, 1993; Çelikel ve Karaçalı, 1995; Çelikel ve ark., 2011) saptanmıştır. Bunun için sıcaklığ $20^{\circ} \mathrm{C}$ 'de sabit tutulan laboratuvarda 12 saat aydinlık (1000 lux, cool white florasan lamba) 12 saat karanlık uygulaması sağlanmıştır.

Uygulamalar ve Denemenin Kurulmast: 7 Ekim 2013 tarihinde 1:1:1 oranında hazırlanan bahçe toprağ1, torf ve perlit karışımındaki ortamlar kullanılarak $15 \mathrm{~cm}$ çapındaki $13.5 \mathrm{~cm}$ boy uzunluğundaki saksılara $(1.6 \mathrm{~L}$ hacminde); her saksıya kültür çeşidi nergis soğanlarından birer tane olacak şekilde dikim işlemi gerçekleştirilmiştir.

Ortalama 7-10 cm boyuna gelen 'Ice Follies' nergislerine (Miller, 2012) 13 Şubat 2014 tarihinde yapraktan sprey şeklinde 0, 1000, 2000 ppm dozlarında ethephon (Efhun) uygulaması yapılmıştır.

Yapılan ölçüm ve gözlemler: Tek çiçekli olan kültür çeşidi nergislerin (Narcissus cv. 'Ice Follies' ) çiçeklerinin açtığı gün çiçeklenme zamanı olarak kabul edilip, dikimden çiçeklenmeye kadar geçen gün sayısı olarak hesaplanmıştır. Yaprak boyu ölçümlerine 'Ice Follies' nergislerinde bitkilerin sadece bir kısmının çıkış yapmış olduğu 31 Ocak 2014 (dikimden 115 gün sonra) tarihinde başlanmıştır. Bitki boyu ise toprak yüzeyinden çiçeklerin sap ile birleştiği kısım arasındaki uzunluk cetvel yardımıyla ölçülerek belirlenmiştir. Bitki boyu ölçümlerine çiçek sürgünlerinin çıkış yapmaya başladığı 18 Şubat 2014 (dikimden 133 gün sonra) tarihinde başlanmıştır. Ölçümlere her hafta düzenli bir şekilde devam edilmiştir. Tek çiçekli 'Ice Follies' nergislerinde çiçek ömrü çiçeğin açtığı gün ile solmasında kadar geçen gün sayısı dikkate alınarak, her uygulama için ortalama bitki ömrü hesaplanmıştır. Ethephon 
uygulamalarına tâbi tutulan Narcissus cv. 'Ice Follies' nergislerinde 10 Mart 2014 tarihinde 'Apogee' marka taşınabilir klorofilmetre ile klorofil ölçümü yapılmıştır. Yapılan ölçüm sonucunda her uygulama için ortalama değerler hesaplanmış ve bu değerler Chlorophyll Content Index (CCI) olarak ifade edilmiştir.

Verilerin değerlendirilmesi: Veriler tamamen şansa bağlı modele (tesadüf parselleri deneme deseni) göre tek yönlü varyans analizi ile değerlendirilmiştir. Araştırma 10 tekerrürlü olarak yürütülmüş, her tekerrürde 1 bitki bulunmaktadır. Elde edilen veriler SPSS paket programında istatistiki analize tâbi tutularak her kimyasal uygulaması için bitkilerin dikimden çiçeklenmeye kadar geçen gün sayısı, yaprak boyu, bitki boyu, çiçek ömrü ve klorofil miktarı ortalama değerleri ile standart hata değerleri $(\bar{X} \pm S \bar{x})$ belirlenmiştir. Tüm analizler istatistiksel olarak $\% 1$ hata sınırları içerisinde hesaplanmış, uygulamalar arasındaki farklılıklar Duncan çoklu karşılaştırma testi ile karşılaştırılmıştır.

\section{Bulgular ve Tartışma}

'Ice Follies' nergislerinde yaprak sprey şeklinde yapılan farklı kimyasal uygulamaların dikimden çiçeklenmeye kadar geçen gün sayısı üzerine etkileri Çizelge 1'de verilmiştir. Kültür çeşidi nergislerde (Narcissus cv. 'Ice Follies') en erken çiçeklenme 150 gün ile kontrolden elde edilirken, en geç çiçeklenme ise 157 gün ile 2000 ppm ethephon uygulamasının yapıldığı bitkilerden elde edilmiştir. Kontrol ve 1000 ppm ethephon uygulamaları arasındaki fark istatistiki açıdan önemsiz bulunmuştur (Çizelge 1).

2000 ppm ethephon uygulamasında çiçeklenmede 7 gün kadar bir gecikme saptanmıştır. 1000 ppm ethephon uygulamasinda ise herhangi bir gecikme saptanmamıştır. Miller ve ark. (2012), farklı nergis çeşitlerine topraktan uygulanan ethephonun çiçeklenmeyi 2-3 gün geciktirdiğini saptamıştır. Benzer şekilde farklı nergis ve lale çeşitlerine uygulanan ethephonun yüksek dozunun çiçeklenmeyi 1-3 gün geciktirdiği bildirilmiştir (Moe, 1980). Ethephon bitkilerde etilen salınımını serbest bırakmaktadır. Dışardan etilen uygulamalarının çiçek gelişimini çeşitli aşamalarda etkilediği ve çiçeklenmeyi geciktirdiği bilinmektedir (Miller ve ark., 2012).

'Ice Follies' nergislerinde yaprak sprey şeklinde yapılan farklı kimyasal uygulamaların yapraklardaki klorofil miktarları üzerine olan etkileri Çizelge 1'de verilmiştir. Yapraklarda yapılan klorofil ölçüm sonuçlarına göre en yüksek klorofil içeriği 82.6 CCI ile 1000 ppm ethephon uygulamasından, en düşük klorofil içeriği ise 75.34 CCI ile kontrolden elde edilmiştir (Çizelge 1). Kullanılan bitki büyüme geciktiricisi ile bitki boyu kontrol altına alınarak, daha kompakt bir yapı oluşmuştur. Bunun sonucu olarak yapraklar daha kısa (Çizelge 2) ve daha kalın bir yapıya sahip olmuştur. Dolayısıyla uygulama yapılmayan bitkilere göre daha küçük alanlara sahip olan yaprakların birim alandaki klorofil miktarının kontrol bitkilerine göre daha fazla olduğu saptanmıştır (Çizelge 1). Ethephonun 2000 ppm dozunda uygulanması ile yapraklarda birim alandaki klorofil içeriğinin 77.47 CCI ile 1000 ppm'e göre daha az olduğu saptanmıştır (Çizelge 1). Etilen salınımını serbest birakan ve bir büyüme engelleyicisi olan ethephonun yüksek dozda uygulanması ile daha yüksek miktarda açığa çıkan etilenin klorofil yıkımını arttırdığı düşünülebilir. Ancak ethephonun yüksek dozda uygulanması ile yapraklardaki klorofil içeriğini düşük dozu kadar olmasa da kontrole göre bir miktar arttırdığı, fakat bu artışın istatistiki açıdan önemli olmadığı saptanmıştır (Çizelge 1). Nitekim, Kim ve ark. (2004), Diospyros kaki L. üzerine yapmış oldukları çalışmada 50,100 ve $200 \mathrm{ppm}$ dozlarında ethephonu sprey olarak uygulamışladır. Ethephonun düşük dozda sprey olarak uygulanması ile yapraklardaki klorofil içeriğinde bir miktar artış olduğunu fakat daha yüksek dozlarda uygulanması ile de klorofil içeriğinde azalma olduğunu saptamışlardır. Buradan kullanılacak olan dozun türe, amaca ve yönteme göre değişiklik gösterdiği anlaşılmaktadır.

Yapraktan sprey şeklinde yapılan farklı dozda ethephon uygulamalarının serada üretim süresince bitki boyu üzerine olan etkileri Şekil 1'de verilmiştir. 3 haftalık değişim sonucunda en kısa bitki boyu $(4.17 \mathrm{~cm})$ 2000 ppm ethephon uygulamasının yapıldığ 1 kültür çeşidi nergislerden en uzun bitki boyu $(13.55 \mathrm{~cm})$ ise kontrolden elde edilmiştir (Çizelge 2, Şekil 1, Şekil 5).

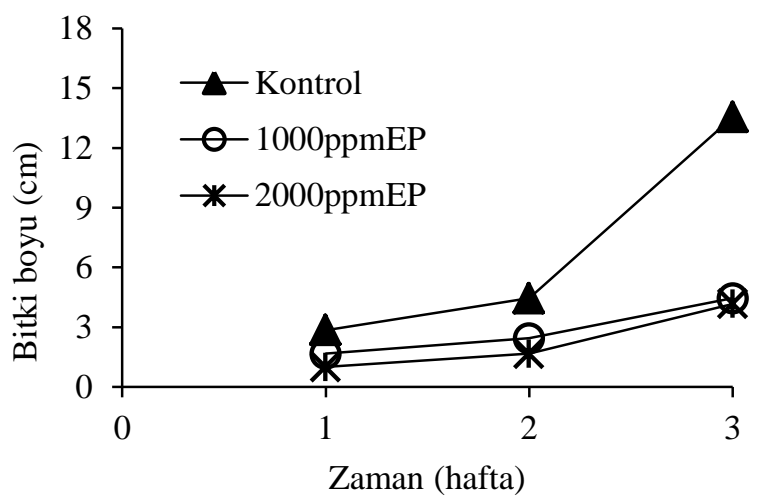

Şekil 1. Kültür çeşidi nergislere (Narcissus cv. 'Ice Follies') yaprak sprey şeklinde yapılan farklı dozda ethephon uygulamalarının serada üretim süresince bitki boyu üzerine olan etkileriÖlçümlere dikimden 133 gün sonra (1. hafta) başlanmıştır EP: Ethephon

2000 ppm ethephon uygulaması ile kontrole göre \%69 oranında daha kısa bitki boyu elde edilmiştir. Uygulamalar arasındaki fark istatistiki açıdan önemli (p $\leq 0.01$ ) bulunmuştur. Ethephonun $1000 \mathrm{ppm}$ dozunda uygulanması ile de $4.45 \mathrm{~cm}$ bitki boyu elde edilmiş ve ethephonun her iki dozu arasında istatistiki anlamda bir fark bulunmaz iken, kontrol bitkileri ile ethephon uygulamaları arasında önemli bir fark tespit edilmiştir ( $\mathrm{p} \leq 0.01)$. Miller ve ark. (2012), farklı nergis çeşitlerine toprak 1slatma şeklinde yapılan 500 ppm ethephon 
uygulamasının bitki boyunu \%34 oranında kısalttığını belirtmiştir. Banon ve ark. (1998), yapmış oldukları çalışmada Liatris spicata'da yapraktan 100-2500 dozlarında uygulanan ethephonun benzer şekilde bitki boyunu kontrol altına aldığını belirtmişlerdir. $\mathrm{Bu}$ çalışmada kontrol bitkileri $129.2 \mathrm{~cm}$ iken 2500 ppm dozunda ethephon uygulanan bitkilerin boyu $70.36 \mathrm{~cm}$ olmuştur. Curcuma alismatifolia bitkisinde yapılan bir diğer çalışmada topraktan uygulanan ethephonun etkili bir şekilde bitki boyunu kontrol altına aldığı ve çiçekleri küçülttüğü belirtilmiştir (Khuankaew ve ark., 2009).
Kültür çeşidi nergislere (Narcissus cv. 'Ice Follies') yapılan ethephon uygulamalarının laboratuvar ortamında bitki boyu üzerine olan etkileri Şekil 3'te verilmiştir. Yapılan istatistiki analiz sonucuna göre her iki hafta içinde uygulamalar arasındaki fark önemli ( $\mathrm{p} \leq$ 0.01) çıkmıştır. En kısa bitki boyu 2000 ppm ethephon uygulamasindan, en uzun bitki boyu ise kontrolden elde edilmiştir. $\mathrm{Bu}$ sonuçlar, uygulamaların bitki boyu üzerine olan etkisinin laboratuvar (ev-ofis) koşullarında da korunduğunu göstermektedir (Şekil 3).

Çizelge 1. Yaprak sprey şeklinde farklı dozda ethephon uygulamalarının yapıldığı kültür çeşidi nergislerde (Narcissus cv. 'Ice Follies') dikimden çiçeklenmeye kadar geçen gün sayısı ile klorofil miktarı. Ortalama \pm Standart Hata $(\bar{X} \pm S \bar{x})$

\begin{tabular}{ccc}
\hline Uygulamalar & $\begin{array}{c}\text { Dikimden çiçeklenmeye } \\
\text { kadar geçen gün sayis1 }\end{array}$ & Klorofil miktarı (CCI) \\
\hline Kontrol & $150.30 \pm 0.68 \mathrm{~b}$ & $75.34 \pm 10.13 \mathrm{~b}$ \\
\hline 1000 ppm ethephon & $150.90 \pm 1.05 \mathrm{~b}$ & $82.60 \pm 5.64 \mathrm{a}$ \\
\hline 2000 ppm ethephon & $157.50 \pm 1.92 \mathrm{a}$ & $77.47 \pm 9.45 \mathrm{~b}$ \\
\hline Sig. (Önem Düzeyi) & 0.001 & 0.009 \\
\hline
\end{tabular}

*Aynı sütunda farklı harflerle gösterilen ortalamalar arasında 0.01 hata sınırları içerisinde önemli fark vardır $(\mathrm{p} \leq 0.01)$

Çizelge 2. Kültür çeşidi nergislere (Narcissus cv. 'Ice Follies') yaprak sprey şeklinde yapılan farklı dozda ethephon uygulamalarının serada üretim sonunda bitki boyu, yaprak boyu ve çiçek ömrü üzerine olan etkileri. Ortalama \pm Standart Hata $(\bar{X} \pm S \bar{x})$

\begin{tabular}{cccc}
\hline Uygulamalar & Bitki boyu $(\mathrm{cm})$ & Yaprak boyu $(\mathrm{cm})$ & Çiçek ömrü (gün) \\
\hline Kontrol & $13.55 \pm 1.66 \mathrm{a}$ & $22.60 \pm 0.82 \mathrm{a}$ & $13.20 \pm 1.30 \mathrm{a}$ \\
\hline 1000 ppm ethephon & $4.45 \pm 0.75 \mathrm{~b}$ & $16.30 \pm 0.56 \mathrm{~b}$ & $13.20 \pm 1.47 \mathrm{a}$ \\
\hline 2000 ppm ethephon & $4.17 \pm 0.44 \mathrm{~b}$ & $14.35 \pm 0.81 \mathrm{~b}$ & $12.00 \pm 0.53 \mathrm{a}$ \\
\hline Sig. (Önem Düzeyi) & 0.00 & 0.00 & 0.076 \\
\hline
\end{tabular}

*Aynı sütunda farklı harflerle gösterilen ortalamalar arasında 0.01 hata sınırları içerisinde önemli fark vardır $(\mathrm{p} \leq 0.01)$

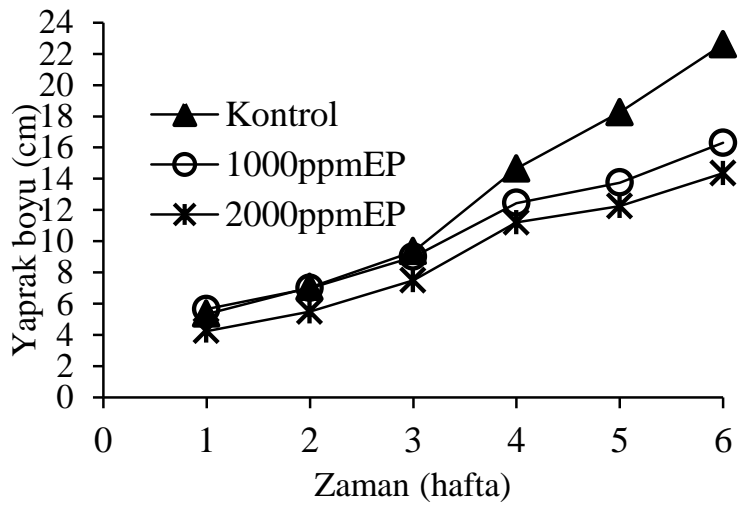

Şekil 2. Kültür çeşidi nergislere (Narcissus cv. 'Ice Follies') yaprak sprey şeklinde yapılan farklı dozda ethephon uygulamalarının serada üretim süresince yaprak boyu üzerine olan etkileri Ölçümlere dikimden 115 gün sonra (1.hafta) başlanmıştır EP: Ethephon

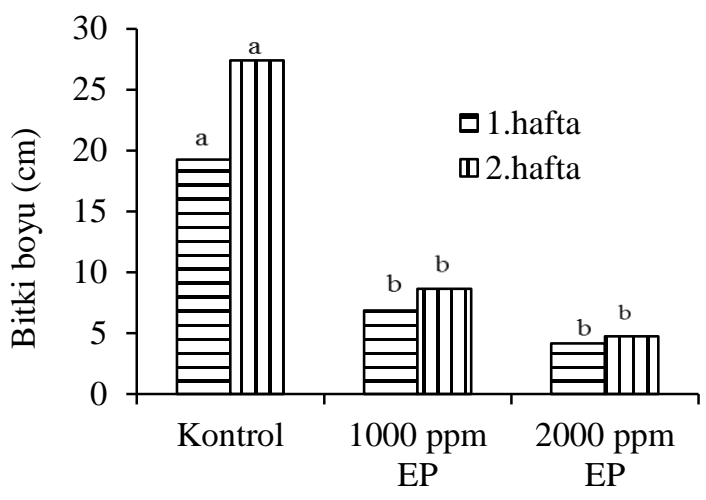

Şekil 3. Kültür çeşidi nergislere (Narcissus cv. 'Ice Follies') yaprak sprey şeklinde yapılan farklı dozda ethephon uygulamalarının laboratuvar ortamında bitki boyu üzerine olan etkileri. Laboratuvar ölçümlerine dikimden 149 gün sonra (1. hafta) başlanmıştır. EP: Ethephon 
Üretim sonrası laboratuvar (ev-ofis) koşullarında 2000 ppm ethephon uygulamasının yapıldığ 1 bitkilerden 4.75 $\mathrm{cm}$ ile kontrole göre $\% 83$ oranında daha kısa bitki boyu elde edilmiştir (Şekil 3). Ethephon uygulamalarının bitki boyu üzerine olan etkisi laboratuvar (ev-ofis) koşullarında da devam ederek, uygulama yapılan bitkiler ile kontrol bitkileri arasındaki boy farkı korunmaya devam etmiştir. Krug ve ark. (2006) 'Tete a Tete' nergis çeşidi üzerine yapmış oldukları çalışmada $1000 \mathrm{ppm}$ ve üzeri dozlarda sprey olarak uygulanan ethephonun üretim sonrası dönemde bitki boyunu kontrol aldığını bildirmişlerdir. Benzer şekilde 8 nergis çeşidi ile 10 lale çeşidinde yapılan çalışmada topraktan uygulanan ethephon ile çiçek sap uzunluğu ve yaprak uzunluğu önemli düzeyde azalmıştır (Moe, 1980).

Ethephon uygulamalarının serada üretim süresince yaprak boyu üzerine olan etkileri Şekil 2'de verilmiştir. 6 haftalık değişim sonucunda en kısa yaprak boyu $(14.35 \mathrm{~cm}) 2000 \mathrm{ppm}$ ethephon uygulamasının yapıldığı kültür çeşidi nergislerden, en uzun yaprak boyu ise kontrolden $(22.6 \mathrm{~cm})$ elde edilmiş, bu bitkilerde yaprak boyu kontrole göre $\% 35$ oranında daha kısa olmuştur (Çizelge 2). $1000 \mathrm{ppm}$ ethephon uygulamasından ise $16.3 \mathrm{~cm}$ ile kontrole göre \%26 oranında daha kısa yaprak boyu elde edilmiştir. Uygulamalar arasındaki fark istatistiki açıdan önemli $(\mathrm{p} \leq 0.01)$ bulunmuştur. Miller ve ark. (2013), farklı nergis çeşitlerine topraktan uygulanan $500 \mathrm{ppm}$ ethephonun yaprak boyunu \%13 oranında kısalttığını belirtmiştir. Briggs (1975) 'Carlton' nergis çeşidine uygulanan ethephonun sap ve yaprak uzunluğunu etkili bir şekilde azalttığını belirtmiştir.

Yapılan farklı dozda ethephon uygulamalarının laboratuvar ortamında yaprak boyu üzerine olan etkileri Şekil 4'de verilmiştir. 'Ice Follies' nergislerinde üretim sonrası laboratuvar (ev-ofis) koşullarında en kısa yaprak boyu $16.12 \mathrm{~cm}$ ile kontrole göre $\% 41$ oranında daha kısa olan 2000 ppm ethephon uygulamasının yapıldığ 1 bitkilerden elde edilmiştir. İstatistiki analiz sonucuna göre her iki hafta içinde uygulamalar arasındaki fark önemli ( $\mathrm{p} \leq 0.01)$ çıkmıştır. Bu sonuçlar, uygulamaların yaprak boyu üzerine olan etkisinin laboratuvar (ev-ofis) koşullarında da korunduğunu göstermektedir (Şekil 4).

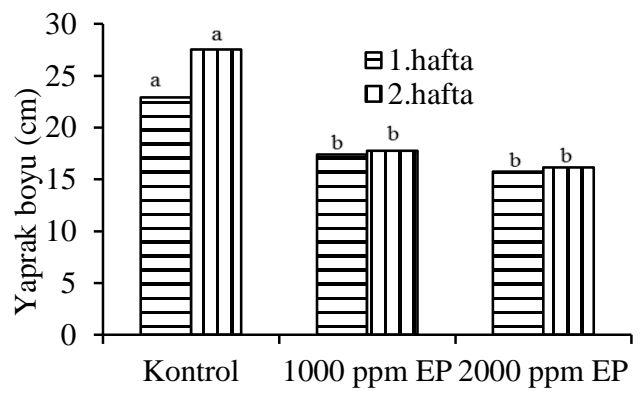

Şekil 4. Kültür çeşidi nergislere (Narcissus cv. 'Ice Follies') yaprak sprey şeklinde yapılan farklı dozda ethephon uygulamalarının laboratuvar ortaminda yaprak boyu üzerine olan etkileri. Laboratuvar ölçümlerine dikimden 149 gün sonra (1.hafta) başlanmıştır EP: Ethephon
Miller ve ark. (2013), farklı nergis çeşitlerine topraktan $500 \mathrm{ppm}$ ethephon uygulamasıyla, üretim sonrası dönemde kontrole göre $\% 45$ daha kısa yaprak boyu elde etmiştir. $\mathrm{Bu}$ sonuçlara göre yapılan uygulamalar üretim sonrasi dönemde laboratuvar koşullarında da yaprak boyu üzerine olan etkisini devam ettirerek, kontrol ile uygulama yapılan bitkiler arasındaki yaprak boyu fark1 korunmaya devam etmiştir. Üretim sonrası dönemde 1000 ve 2000 ppm uygulamasının yapıldığı bitkilerde yaprak boyu açısından istatistiki olarak fark bulunmamış $(\mathrm{p}>0.05)$, kontrol ile uygulamalar arasındaki farkın ise istatistiki olarak önemli olduğu saptanmıştır.

'Ice Follies' nergislerinde çiçek ömrünün 12-13 gün arasında değiştiği belirlenmiştir. Miller (2002), sümbülde boy kontrolü amaçlı ethephon uygulamasının çiçek ömrünü kısalttığını belirtmiştir. Yapılan çalışmada en kısa çiçek ömrü 2000 ppm ethephon uygulamasının yapıldığı bitkilerde 12 gün olarak saptanırken, kontrol ve $1000 \mathrm{ppm}$ ethephon uygulamasının yapıldığ bitkilerde ise 13.2 gün olduğu belirlenmiştir. Kontrol ve $2000 \mathrm{ppm}$ ethephon uygulamaları arasında çiçek ömrü bakımından sadece 1 günlük fark bulunduğu ve bu farkın istatistiki açıdan önemli düzeyde olmadığı tespit edilmiştir.

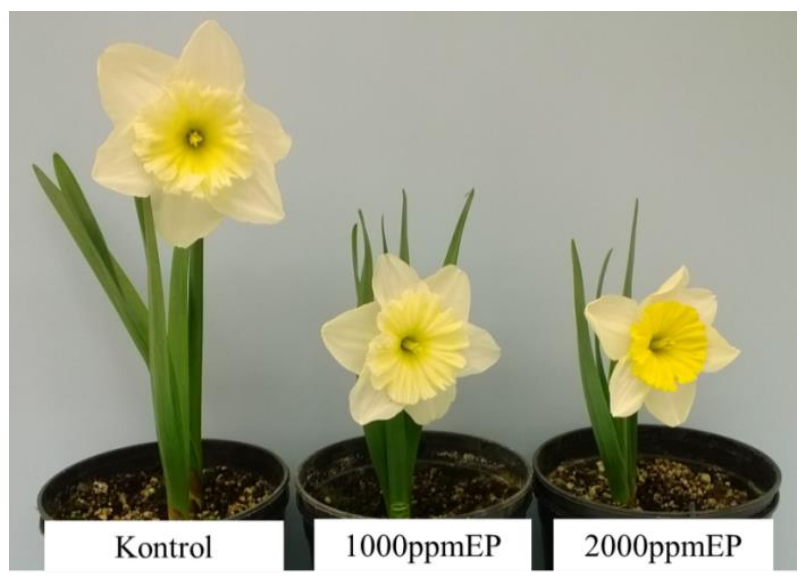

Şekil 5. Yapraktan sprey şeklinde ethephon uygulamalarının yapıldığ 1 kültür çeşidi nergisler (Narcissus cv. 'Ice Follies') EP: Ethephon

\section{Sonuç}

'Ice Follies' nergislerinde yapraktan sprey şeklinde farklı dozlarda ethephon uygulamaları ile bitki boy kontrolü sağlanarak kompakt yapılı nergisler elde edilmiştir. Soğanlı çiçeklerde kompakt yapının sağlanması ve korunması hem taşıma ve paketleme sirasinda otsu yapida olan bu bitkilerin zarar görmemesi, hem de üretim sonrası dönemde 1şı̆̆ın az olduğu ev-ofis ortamlarında bitki boyunun daha fazla uzamaması ve bitki formunun korunması açısından önemlidir. $\mathrm{Bu}$ çalışma ile sprey şeklinde uygulanan ethephon bitki boyu yanında yaprak boyunu da kısaltmış ve yaprakların birim alandaki klorofil içeriğinde de bir miktar artışa sebep olduğu 
belirlenmiştir. Dolayisıyla daha sik dokulu nergisler elde edilmiş, üretim sonrası koşullarda çiçek saplarında meydana gelebilecek olan cılızlaşma ve eğilip bükülmeler engellenmiştir. Ayrıca çiçek ömrü bakımından da uygulamaların herhangi bir olumsuz etkisi olmamıştır. Yapılan ethephon uygulamasının her iki dozu arasinda incelenen parametrelerden bitki ve yaprak boyu ile çiçek ömrü açısından istatistiki olarak bir fark bulunmamıştır. Çiçeklenme zamanı açısından 2000 ppm ethephon uygulamasının çiçeklenmeyi bir miktar geciktirdiği, $1000 \mathrm{ppm}$ ethephon uygulamasının yapıldığ 1 nergislerde ise herhangi bir gecikmenin olmadığı saptanmıştır.

Sonuç olarak, 1000 ppm ethephon uygulamasının yapıldığı nergislerin çiçeklenme zamanında herhangi bir gecikme olmaması, yaprakların birim alandaki klorofil içeriğinin daha yüksek olması ve bitki boy kontrolünü sağlaması göz önünde bulundurularak, daha düşük dozda kimyasal kullanımı nedeniyle 1000 ppm ethephon uygulaması önerilmektedir. Ayrıca diğer uygulamalara nazaran yapraktan sprey yöntemi uygulanması daha kolay ve pratik bir yöntem olarak önerilmektedir.

\section{Teșekkür}

$\mathrm{Bu}$ çalışma Ondokuz Mayıs Üniversitesi tarafindan PYO.ZRT.1904.13.009'nolu Bilimsel Araştırma Projesi ile desteklenmiştir. Çalışmada kullanılan ethephon (Efhun) Agrobest Grup Tarım İlaçları Tohum İmalat İthalat İhracat Sanayi ve Ticaret Anomim Şirketi Marmara Bölge Müdürü Sayın Raşit ATLI tarafindan sağlanmıştır.

\section{Kaynaklar}

BañóN, S., González, A., Fernández J. A., Franco J. A., 1998. The effect of ethephon on the growth and development of Liatris spicata. The Journal of Horticultural Science and Biotechnology, 73(6):851855. doi: 10.1080/14620316.1998.11511059.

Briggs, J.B., 1975. The effects on growth and flowering of the chemical growth regulator ethephon on narcissus and ancimidol on tulip. Acta Hort., 47: 287-296.

Burnie, G., Forrester, S., Greig, D., Guest, S., Harmony, M., Hobley, S., Jackson, G., Lavarack, P., Ledgett, M., McDonald, R., Molyneux, B., Moodie, D., Moore, J., Nortyh, T., Newman, D., Pienaar, K., Purdy, G., Silk, J., Ryan, S., Schien G., 1999. Botanica, 3rd. ed., Sing Cheong Printing Ltd., Hong Kong.

Currey, C.J., Lopez, R.G., 2014 Applying plant growth retardants for height control, Commercial Greenhouse and Nursery Production. Purdue Universty https://www.extension.purdue.edu/extmedia/HO/HO -248-W.pdf (Ziyaret tarihi: 17.04.2014).

Çelikel, F.G., Karaçalı, İ., 1991. A study of longevity of cut carnations (Dianthus caryophyllus L.) grown in
Yalova (Istanbul). Acta Horticulturae, Postharvest Physiology of Ornamentals, 298:11-118.

Çelikel, F.G., 1993. Yalova (İstanbul) bölgesinde yetiştirilen karanfillerin kesim sonrası dönemde dayanım güçleri üzerinde bir araştırma. Doktora Tezi. Ege Üniversitesi, Fen Bilimleri Enstitüsü, 169 s, İzmir.

Çelikel, F.G., Karaçalı, İ., 1995. Effect of preharvest factors on flower quality and longevity of cut carnations (Dianthus caryophyllus L.). Acta Horticulturae, Postharvest Physiology of Ornamental Plants, 405: 156-163.

Çelikel, F.G., Joyce, D.C., Faragher, J.D., 2011. Inhibitors of oxidative enzymes affect water uptake and vase life of cut Acacia holosericea and Chamelaucium uncinatum stems. Postharvest Biology and Technology, 60: 149-157. doi:10.1016/j.postharvbio.2010.12.009.

Çelikel, F.G., Demir, S., Kebeli, F., Sarı, Ö., 2016. Çiçek soğanlarının kesme çiçek ve saksıda yetiştiriciliği üzerine araştırmalar. Yalova Atatürk Bahçe Kültürleri Merkez Araştırma Enstitüsü Dergisi, 45:873-876.

Demir S., Çelikel F.G., 2013. Soğanlı çiçeklerin saksıda yetiştiriciliğinde bitki boyunun kimyasal yolla kontrol edilmesi. V. Süs Bitkileri Kongresi, Cilt 2, 830-834, 6-9 May1s, Yalova.

Haver, D.L., Schuch, U.K., Lovatt, C.J., 2003. Exposure of petunia seedlings to ethylene decreased apical dominance by reducing the ratio of auxin to cytokinin. Journal of Plant Growth Regulation, 21:459-468. doi: 10.1007/s00344-002-0022-3

Kebeli, F., Çelikel, F.G., 2013. Doğal ve kültür çeşidi nergis soğanında dikim zamanının çiçek kalitesi ve çiçeklenme süresi üzerine etkileri. V. Süs Bitkileri Kongresi, Cilt 2, 823-829, 6-9 Mayıs, Yalova.

Kim, Y.H., Lim, S.C., Youn, C.K., Yoon, T., Kim, T.S., 2004. Effect of ethephon on fruit quality and maturity of 'Tone Wase' Astringent Persimmons (Diospyros kaki L.). Acta Hort., 653: 187-191.

Khuankaew T., Ohyama, T., Ruamrungsri S., 2009. Effects of ethephon application on growth and development of Curcuma alismatifolia Gagnep. Niigata University Faculty of Agriculture Research Report 62(1):9-15.

Krug, B.A., Whipker, B.E., McCall, .I, Dole, J.M., 2006. Narcissus response to plant growth regulators. HortTechnology, 16:129-132.

Miller, W.B., 2002. Using PGRs on spring bulbs. Greenhouse Product News, 8-14.

Miller, W.B., 2012. Current status of growth regulator usage in flower bulb forcing in North America. Floriculture and Ornamental Biotechnology, 6:3544.

Miller, W.B., Mattson, N.S., Xie, X., Xu, D., Currey, C.J., 2012. Ethephon substrate drenches inhibit stem extension of floriculture crops. Hortscience, 47:1312-1319.

Miller, W., Mattson, N., Lopez, R., Currey. C., 
Clemens, K., Olrich, M., Runkle, E., 2013. A new height control possibility for daffodils and hyacinths. Greenhouse Product News, 20-23.

Miller, W.B., Olberg, M.W., 2016. Novel ethephon application methods for narcissus. Hortscience, 51(10):1245-1250. doi: 10.21273/HORTSCI11188-

16.
Moe, R., 1980. The use of ethephon for control of plant height and daffodils and tulips. Acta Hort., 109 : 197-204. 